\title{
Occurrence of anemia in Holstein calves in the first month after birth
}

\section{Ocorrência de anemia em bezerras da raça Holandesa no primeiro mês de vida}

\author{
Fernando José Benesi ${ }^{1 *}$; Júlio Augusto Naylor Lisbôa ${ }^{2}$; Marta Lizandra do Rêgo \\ Leal $^{3}$; Carolina de Lara Shecaira ${ }^{4}$; Rogerio Batista dos Santos ${ }^{5}$
}

\begin{abstract}
The high mortality rates of calves has encouraged research of the physiological mechanisms that control birth and adaptation of newborns to extrauterine life, to allow early identification of the presence of disease characteristics during the neonatal period. This study aimed to determine the occurrence of anemia in Holstein calves in the first month after birth and address the lack of information on the subject in neonates raised under national conditions. In total, 385 animals, 199 from refrigerated type A raw milk producing and 186 from refrigerated raw milk producing dairy farms, were surveyed. Anemia was observed in $14.3 \%$ of the heifers (55/385), with a higher frequency in the farms producing type A milk $(18.6 \%, 37 / 199)$. It was concluded that the frequency of anemia is significant in neonates of the studied breed, particularly in those with more technified properties (type A milk), with this condition being, in most cases, a possible etiology of iron-deficiency.
\end{abstract}

Key words: Calves. Anemia. Blood count. Neonates.

\section{Resumo}

As altas taxas de mortalidade de bezerros têm incentivado pesquisas para o estudo dos mecanismos fisiológicos que controlam o nascimento e a adaptação desses neonatos à vida extrauterina, de modo a permitir a identificação precoce da higidez ou presença de enfermidades características do período neonatal. Este estudo para o estabelecimento da ocorrência de anemia em bezerras da raça Holandesa no primeiro mês de vida considerou 385 animais, sendo 199 provenientes de granjas leiteiras (produtoras de leite cru refrigerado do tipo A) e 186 de estábulos leiteiros (produtores de leite cru refrigerado), e permitiu o levantamento motivado pela ausência de informações sobre o tema em neonatos criados em condições nacionais. A anemia foi observada em 14,3\% das bezerras (55/385), tendo frequência maior nas granjas produtoras de leite tipo A $(18,6 \% ; 37 / 199)$. Concluiu-se que a frequência de anemia é significativa em bezerros neonatos da raça estudada, particularmente nas propriedades mais tecnificadas (leite A), tendo essa condição, na maioria dos casos, uma possível etiologia ferropriva.

Palavras-chave: Bezerras. Anemia. Hemograma. Neonatos.

1 Prof. Titular, Departamento de Clínica Médica, Universidade de São Paulo, USP, São Paulo, SP, Brasil. febencli@usp.br

2 Prof. Associado, Departamento de Clínicas Veterinárias, Centro de Ciências Agrárias, Universidade Estadual de Londrina, UEL, Londrina, PR, Brasil. janlisboa@uel.br

3 Prof A Associado II, Departamento de Clínica de Grandes Animais, Universidade Federal de Santa Maria, UFSM, Santa Maria, RS, Brasil.mlizandra@smail.ufsm.br

4 Prof ${ }^{a}$ Adjunta, Curso de Medicina Veterinária, Universidade São Judas Tadeu, Campus Unimonte, USJT, Santos, SP, Brasil. carolina.shecaira@gmail.com

5 Prof., Titular, Curso de Medicina Veterinária, Universidade Paulista, UNIP, São Paulo, SP, Brasil. santos.rogerio@usp.br

* Author for correspondence 


\section{Introduction}

The neonatal period is a stage of intense development of vital functions and adaptation in newborn calves, and morbidity and mortality rates are high during this period (BENESI, 1993). Anemia is among the causes of morbidity and mortality and is a condition that results from the inability of the erythropoietic tissue to restore erythrocytes in a timely manner to maintain the so-called physiological limit of the erythrocyte components of the blood (BENESI, 1985). Anemia, as a debilitating condition, can contribute to morbidity and mortality rates and is thus, an important issue to be addressed to reduce losses.

A bibliographic survey of the incidence of anemia in calves showed that there is almost no information on the occurrence of anemia in newborn bovine animals raised in national conditions, despite isolated records of its incidence (BENESI et al., 1999). However, the frequency of anemia in calves varies as reported by some studies. In Jersey and Holstein cows in the United States, $15.8 \%$ of the animals showed this condition (TENNANT et al., 1975). Similarly, in Iranian herds, the percentage of anemic Holstein calves was 17.7 \% (RAMIN et al., 2012). In the only study conducted in Brazil of crossbred calves, $30.7 \%$ five-day-old animals were found anemic (RENGIFO et al., 2010).

The etiology of anemia is very variable and iron deficiency is the most frequently reported cause (BIRGEL, 1972; TENNANT et al., 1975; REECE, 1980; WEISS, 2010). It has been suggested that it can develop during the fetal period due to impairments in iron transfer from the mother to the fetus (TENNANT et al., 1975), iron-deficient diets substituting milk as the only provided food (REECE, 1980), or inflammatory conditions that promote iron sequestration (WEISS, 2010). Other causes frequently described are massive endo- or ectoparasite infestations (DRYDEN et al., 1993; BENESI et al., 1998; WEISS, 2010).
Hemolytic anemias are also reported, although less frequently. The main reported causes for this condition are erythropoietic porphyria (KANEKO; MILLS, 1970), congenital anaplasmosis (BENESI et al., 1999), and neonatal isohemolytic anemia (LUTHER et al., 1985; BAXTER, 1996).

Therefore, the present study was developed to investigate the frequency of anemia in neonatal Holstein calves, considering the type of milk produced in the dairy farm.

\section{Material and Methods}

In total, 385 Black and White Holstein calves were evaluated for up to 30 days after birth. Of these, 199 were raised in dairy farms producing refrigerated type A raw milk ( $\mathrm{n}=7$ farms) and 186 in those producing refrigerated raw milk (n $=15$ farms). The dairy farms were located in 14 different municipalities of the State of São Paulo, Brazil, comprising the dairy basins near Campinas, São Carlos, and São José dos Campos (LISBÔA et al., 2002). The management pattern on all farms was similar and the calves were kept individually in covered housing facilities (stalls or cages) or outdoors (hutch housing system) and received 4 liters of milk or milk substitute per day divided into two meals, in addition to water and pelleted feed ad libitum.

To assess the health status, the heifers were subjected to a physical examination using the methods proposed by Dirksen et al. (1993) and Feitosa and Benesi (2014). The animals were divided into two groups: a) experimental - heifers diagnosed as anemic $(\mathrm{n}=55)$; and $\mathrm{b})$ control an equal number of animals $(\mathrm{n}=55)$ considered clinically and hematologically healthy. The heifers of the control group were selected according to age and type of dairy production (refrigerated type A raw milk or refrigerated raw milk) to be similar to the anemic animals. 
Two blood samples were collected from each animal by puncturing the jugular vein (with a 25 $\mathrm{mm} \times 8 \mathrm{~mm}$ needle), with previous antisepsis, for hematological and biochemical assessment; one, using vacuum tubes containing the anticoagulant, ethylenediaminetetraacetic acid (EDTA - $1 \mathrm{mg} /$ $\mathrm{mL}$ of blood) and the other, using tubes without the anticoagulant. The erythrogram was determined for each aliquot with the anticoagulant.

The red blood cell count was performed using a hemocytometer (a modified Neubauer chamber). The absolute hematimetric indexes were calculated based on the red blood cell count $/ \mathrm{mm}^{3}$ (He), hemoglobin concentration $(\mathrm{Hb}$; determined by the cyanmethemoglobin method), globular volume ( $\mathrm{GV}$; determined by the micromethod), reticulocyte count (performed on blood smears previously subjected to supravital staining with $1 \%$ brilliant cresyl blue and then stained by the Rosenfeld method), and hemoparasite screening (performed on blood smears stained by the Rosenfeld method using the methods standardized by Birgel (1982) and Jain (1993).

Animals with a globular volume lower than $25 \%$ were considered anemic, as established by Tennant et al. (1975). Serum iron levels were determined in serum obtained from blood samples collected in tubes without the anticoagulant, using the colorimetric method without deproteinization, following the recommendations of Dixon (1973). Serum bilirubins were determined according to the method of Jendrassik and Grof (1938), also using serum from blood samples collected in tubes without the anticoagulant.

The $t$-test was used to compare the groups (experimental vs. control) and the total number of heifers $(\mathrm{n}=55)$, heifers from farms producing refrigerated type A raw milk $(\mathrm{n}=37)$, and heifers from farms producing refrigerated raw milk (n $=18$ ) were analyzed separately. The comparison between the anemic heifers of the two types of dairy farms was also performed using the $t$-test. The chi- square test was used to determine if the anemia was associated with the type of milk produced by the dairy farm. For all tests, an error probability of $5 \%$ was accepted (ZAR, 1984).

\section{Results and Discussion}

The results obtained in the present study are shown in Table 1. Analysis of the erythrograms of the 385 animals studied showed that $14.29 \%$ of these animals were anemic $(n=55)$. Of these heifers presenting anemia, 37 originated from farms producing refrigerated type A raw milk and 18 from farms producing refrigerated raw milk. Regarding the erythrogram, all the components observed for anemic animal groups were lower than those obtained for the control group, regardless of the type of milk production $(p<0.05)$ and $(p<$ $0.01)$. However, there were no differences in the severity of anemia between the groups according to the type of milk produced. The number of reticulocytes showed no differences between the groups with and without anemia and thus, it was not possible to conclude that anemic animals have greater red blood cell regeneration. According to Tennant et al. (1975), during the neonatal period, fetal erythrocytes are eliminated, causing an anemia that is considered physiological, where a greater number of circulating reticulocytes is observed, which can conceal anemias caused by other factors, such as congenital hemoparasitosis. The analysis of the absolute hematimetric indexes showed significant reductions in the animals with anemia, irrespective of type of milk produced, except for the Medium Corpuscular Hemoglobin Concentration (MCHC), which showed no differences between the groups with and without anemia in animals from the dairy farms producing refrigerated raw milk. Hypochromic or normochromic microcytic anemias could be evidenced from the results obtained (STOCKHAM; SCOTT, 2011; HARVEY, 2000; JAIN, 1986; BIRGEL, 1982). 


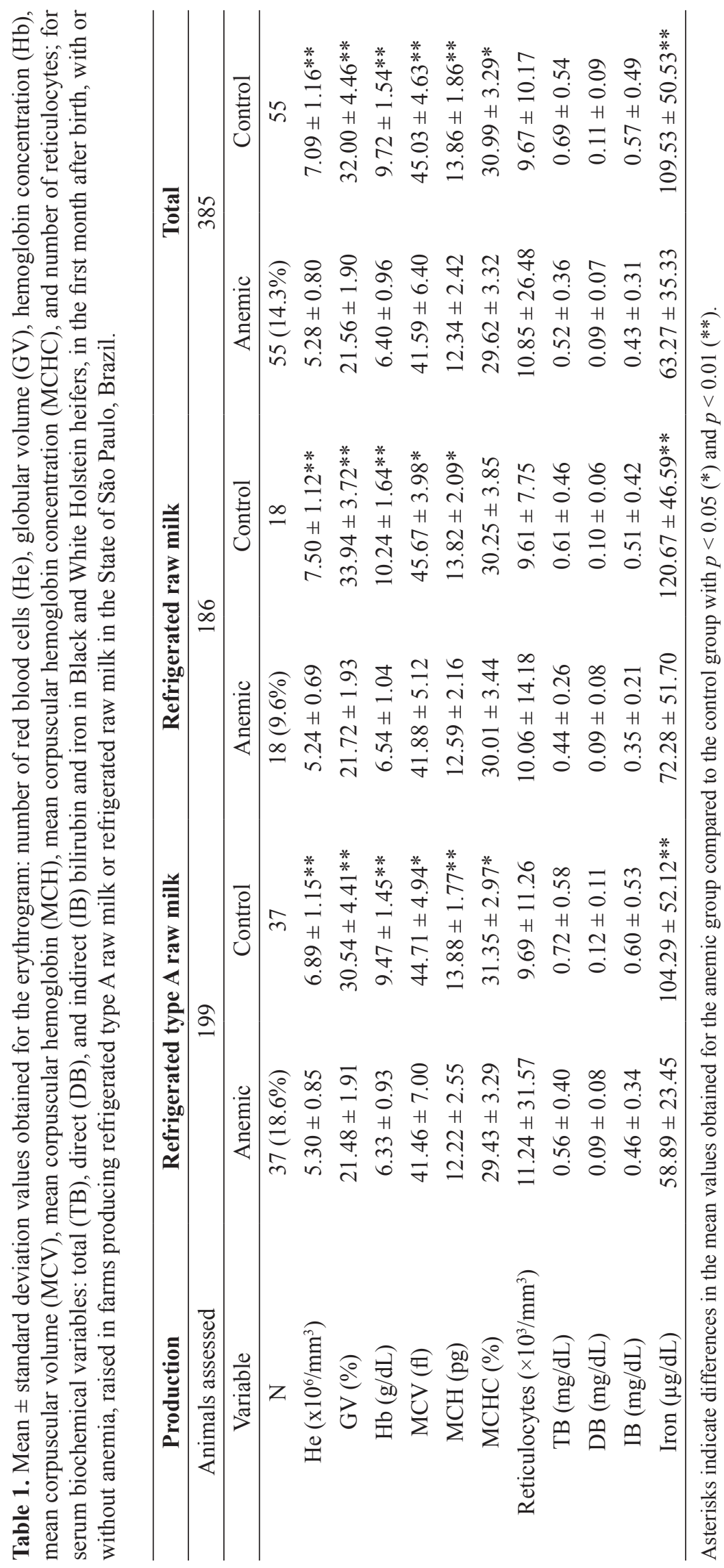


When the frequency of anemic animals was compared according to the type of milk produced, it was observed that anemia was more frequent in the farms producing refrigerated type A raw milk $(p=0.019)$. It is known that these farms have the common practice of administering only a milk substitute instead of in natura milk. Therefore, the use of a poor quality substitute, that is, with a crude protein content of less than $20 \%$, low lactose content or high concentrations of vegetable protein, or with insufficient iron concentrations or even with a handling error during preparation, such as incomplete dilution of the substitute in water causing the product to be concentrated at the bottom of the bottle, may have contributed to the observed result.

Analyzing the age of the anemic heifers, it is worth noting that $78.2 \%$ of the cases occurred within 14 days of birth, with $40 \%$ between birth and seven days of birth (22/55) and $38.2 \%$ in the second week (21/55). This result can be explained by the high metabolic demand of the heifers, as it is a period of intense growth and low iron availability (low iron content in milk and colostrum and low organic mineral reserve). Thus, most anemias during this period are caused by iron deficiency (WEISS, 2010).

Biochemical determinations carried out for a possible elucidation of the hemolytic or iron deficiency etiology of the anemias, through the analysis of serum bilirubin and iron levels, respectively, confirmed that, for most cases, the anemic processes were not hemolytic but were caused by iron deficiency, as total and indirect bilirubin levels were not increased in the group of anemic animals (WEISS, 2010; TENNANT et al., 1975). On the other hand, serum iron concentrations were lower in the anemic animals $(p<0.01)$, corresponding to approximately $58 \%$ of the levels observed in animals without anemia. In addition, values with smaller magnitudes were observed in heifers originating from farms producing type A milk.
Further investigating the probable etiology of anemia, hemoparasites were observed in blood smears in about $20 \%$ of the anemic animals (11/55), with a predominance of Anaplasma sp. However, reticulocytosis and hyperbilirubinemia, which are conditions in animals affected by anaplasmosis, as described by Stockham and Scott (2011), were not observed in the anemic group. This observation can be explained by the fact that most of the anemic processes observed in these animals had an iron deficiency etiology. It should be noted that about $63.6 \%$ of the heifers with hemoparasites were less than 16 days old, with a particular occurrence in the first week after birth and exclusively by Anaplasma sp. Consistent with a previous observation (BENESI et al., 1999), such facts suggest that the transmission of this hemoparasitosis was transplacental or congenital, since the life span of these heifers would not be compatible with an infection transmitted by ticks in the extrauterine environment, requiring a longer incubation period to manifest.

Of note, the presence of hemoparasites was not observed in any of the animals in the control group.

\section{Conclusions}

Based on the observations in this study, it can be concluded that the frequency of anemia is significant in Holstein heifers $(14.3 \%)$ raised in national conditions, particularly in farms producing refrigerated type A raw milk. Most cases of anemia are caused by iron deficiency, as suggested by the significantly lower serum iron levels and the predominance of hypochromic/normochromic microcytic anemia. In addition, hemoparasites were observed in about $20 \%$ of anemic animals, indicating a possible transplacental transmission of Anaplasma sp. as described by Benesi et al. (1999). However, even in these animals, the expected reticulocytosis and indirect hyperbilirubinemia were not observed, as the iron deficiency nature of the pathogenesis of the anemic process predominated over the hemolytic. 


\section{References}

BAXTER, K. Haemolytic anaemia in an embryo transfer calf. Veterinary Record, London, v. 138, n. 14, p. 339342, 1996.

BENESI, F. J. Diagnóstisco e terapia das anemias em caprinos. In: D'ANGELINO, J. L. Manejo, patologia e clínica de caprinos. São Paulo: SPMV, 1985. p. 171-191.

BENESI, F. J. Síndrome asfixia neonatal dos bezerros. Importância e avaliação crítica. Arquivos Escola Medicina Veterinária da UFBA, Salvador, v. 16, n. 1, p. 38-49, 1993.

BENESI, F. J.; HOWARD, D. L.; CARDOSO DE SÁ, C. S.; BIRGEL JÚNIOR, E. H. Relato de um caso de transmissão transplacentária de anaplasmose bovina. Observações clínico-laboratoriais. Revista Brasileira de Ciência Veterinária, Niterói, v. 6, n. 3, p. 175-176, 1999. DOI: $10.4322 /$ rbcv.2015.163

BENESI, F. J.; PEREIRA, M. C.; CARDOSO DE SÁ, C. S.; HOWARD, D. L. ; TEIXEIRA, C. M. C.; LARSSON, C. E. Cat flea infestation in a newborn Jersey calf in Brazil. Brazilian Journal of Veterinary Parasitology, Jaboticabal, v. 7, n. 2, p. 157-160, 1998.

BIRGEL, E. H. Haematologische untersuchungen bein kaelbern der rasse deutsches Schwarzbuntes Rind in den ersten 14 lebenstagen. 1972. These (Doktorarbeit in Gynäkologie und Geburtshilfe) - Tieraetztliche Hochschule, Hannover.

BIRGEL, E. H. Hematologia clínica veterinária. In: BIRGEL, E. H.; BENESI, F. J. Patologia clínica veterinária. São Paulo: Sociedade Paulista de Medicina Veterinária, 1982. p. 2-34.

DIRKSEN, G.; GRÜNDER, H. D.; STÖBER, M. Rosenberger - exame clínico dos bovinos. In: DIRKSEN, G. Sistema digestivo. Rio de Janeiro: Guanabara Koogan, 1993. p. 166-228.

DIXON, K. Annals of Clinical Biochemistry, Kent, v. 10, n. 5, p. 127-127, 1973.

DRYDEN, M. W.; BROCE, A. B.; MOORE, W. E. Severe flea infestation in dairy calves. Journal American Veterinary Medical Association, Nova York, v. 203, n. 10, p. 1488-1452, 1993.

FEITOSA, F. L. F.; BENESI, F. J. Semiologia de animais recém-nascidos. In: FEITOSA, F. L. F. Semiologia: a arte do diagnóstico. 3. ed. São Paulo: Editora Rocca, 2014. p. 69-97.

HARVEY, J. W. Microcytic anemias. In: FELDMAN, B. V.; ZINKL, J. G.; JAIN, N. C. Schalm's veterinary hematology. Philadelphia: Lippincott Williams\& Wilkins, 2000. p. 2000-2009.

JAIN, N. C. Examination of the blood and bone marrow.
In: JAIN, N. C. (Ed.). Essentials of veterinary hematology. Philadelphia: Williams \& Wilkins, 1993. p. 1-18.

JAIN, N. C. Schalm's veterinary hematology. $4^{\text {th }}$ ed. In: JAIN, N. C. Cattle: normal hematology with comments on response to disease. Philadelphia: Lea \& Febiger, 1986. p. 178-207.

JENDRASSIK, L.; GROF, P. Vereinfachte photometrische Methoden zur Bestimmung des Blutbilirubins. Biochemische Zeitschrift, Berlin, v. 297, n. 1-2, p. 81-9, 1938.

KANEKO, J. J.; MILLS, R. Hematological and blood chemical observations in neonatal normal and porphyric calves in early life. Cornell Veterinarian, Ithaca, v. 60, n. 1, p. 52-60, 1970.

LISBÔA, J. A. N.; BENESI, F. J.; LEAL, M. L. R.; TEIXEIRA, C. M. C. Efeito da idade sobre o equilíbrio ácido-básico de bezerras sadias no primeiro mês de vida. Brazilian Journal of Veterinary Research and Animal Science, São Paulo, v. 39, n. 3, p. 136-142, 2002.

LUTHER, D. G.; COX, H. U.; NELSON, W. O. Screening for neonatal isohemolytic anaemia in calves. American Journal of Veterinary Research, Chicago, v. 46, n. 5, p. 1078-1079, 1985.

RAMIN, A. G.; ASRI-REZAEI, S.; PAYA, K.; EFTEKHARI, Z.; JELODARY, M.; AKBARI, H.; RAMIN, S. Evaluation of anemia in calves up to 4 months of age in Holstein Dairy herds. VETSCAN, v. 7, n. 1, p. 87-92, 2012.

REECE, W. O. Acid-Base balance and select hematologic, eletrolyte and blood chemical variables in calves: MilkFed vs convertionally fed. American Journal of Veterinary Research, Chicago, v. 41, n. 1, p. 109-113, 1980.

RENGIFO, S. A.; SILVA, R. A.; BOTTEON, R. C. C. M.; BOTTEON, P. T. L. Hemograma e bioquímica sérica auxiliar em bezerros mestiços neonatos e ocorrência de enfermidades. Arquivo Brasileiro de Medicina Veterinária e Zootecnia, Belo Horizonte, v. 62, n. 4, p. 993-997, 2010. DOI: 10.1590/S0102-09352010000400033

STOCKHAM, S. L.; SCOTT, M. A. Fundamentos de patologia clínica. 2. ed. Rio de Janeiro: Guanabara Koogan, 2011.

TENNANT, B.; HARROLD, D.; REINA-GUERRA, M. KANEKO, J. J. Hematology of the neonatal calf III. Frequency of congenital iron deficiency anemia. Cornell Veterinarian, Ithaca, v. 65, n. 4, p. 543-556, 1975.

WEISS, D. J. Iron and cooper deficiencies and disorders of iron metabolism. In: WEISS, D. J.; WARDROP, K. J. Schalm's veterinary hematology. $6^{\text {th }}$ ed. Iowa: Blackwell Publishing, 2010. cap. 26, p. 167-171.

ZAR, J. H. Bioestatistical analysis. $2^{\text {th }}$ ed. Englewood Cliffs: Prentice-Hall, 1984. 450 p. 